\title{
ADRENERGIC INNERVATION OF THE RAT HYPOTHALAMUS
}

M. PALKOVITS, ÉVA MEZEY, L. ZÁBORSZKY, ANDREA FEMINGER, D.H.G. VERSTEEG, H.J.L.M. WIJNEN, W. DE JONG, M.I.K. FEKETE, J.P. HERMAN and B. KANYICSKA

Ist Department of Anatomy, Semmelweis University Medical School, Budapest (Hungary)

(D.H.G.V., H.J.L.M.W. and W. de J.) Rudolf Magnus Institute for Pharmacology, University of Utrecht, Utrecht (The Netherlands)

and

(M.I.K.F., J.P.H. and B.K.) Institute of Experimental Medicine, Hungarian Academy of Sciences, Budapest (Hungary)

(Received March 24th, 1980)

(Accepted April 9th, 1980)

\section{SUMMARY}

The adrenergic innervation of the hypothalamus was studied by measuring hypothalamic adrenaline levels following surgical transection of the lower brain stem or electrolytic lesion of the medullary adrenaline-containing cell groups. The adrenaline levels in some hypothalamic nuclei and in the median eminence showed a slight decrease after partial transection of the medulla oblongata, whilst there was a pronounced decrease (by 59-78\%) 7-10 days following total hemisection or unilateral lesion of the $\mathrm{C} 1$-catecholaminergic cell group in the medulla oblongata.

The hypothalamus is relatively rich in adrenaline-containing nerve terminals which can be well visualized with the phenylethanolamine N-methyltransferase (PNMT) immunofluorescence technique $[6,9]$. The adrenaline concentration $[8,12$, 24] and PNMT activity $[9,21]$ in the hypothalamus are the second highest in the brain, only those in certain medullary regions being greater. Fluorescence histochemistry showed only adrenaline-containing cell bodies in two circumscribed areas of the medulla oblongata ( $\mathrm{C} 1$ and $\mathrm{C} 2$ cell groups) [6]. The $\mathrm{C} 1$ cell group consists of adrenaline-containing cells in the medial part of the lateral reticular nucleus and thus appears to belong to the rostral part of the A1 noradrenergic cell group [2] which occupies the same location. The $C 2$ cell group consists of adrenaline-containing perikarya under the caudal part of the IVth ventricle, located 
in the region of the nucleus of the solitary tract (NTS) as well as medially and ventrally to the nucleus [6]; the distribution of the $C 2$ cell group thus appears to overlap with the rostral component of the A2 noradrenergic cell group [2]. It is logical to assume the medulla oblongata to be the source of the hypothalamic adrenergic fibers. The existence of neural connections between the medulla oblongata, especially the areas corresponding to the $\mathrm{C} 1$ and $\mathrm{C} 2$ cell groups (lateral reticular nucleus and the NTS) and the hypothalamus has been proved histologically (retrograde tracing with HRP) [3, 5, 16, 18, 25], autoradiographically [18] and electron microscopically $[15-17,25]$. These methods are not suitable to determine the chemical characteristics of the connections. Perikarya containing other neurotransmitters (enkephalin [7, 21], substance $P$ [4] and neurotensin [22]) have also been detected in the above areas, particularly in the NTS, and there are numerous perikarya whose chemical characteristics are still unknown. The connection between the medulla oblongata and the hypothalamus as shown by immunocytology (retrograde transport of dopamine- $\beta$-hydroxylase antibody) [20] might represent the projection of the adrenaline- as well as of the noradrenalinecontaining neurons.

Wistar rats, weighing between 190 and $210 \mathrm{~g}(\mathrm{n}=112)$, were kept under standard laboratory conditions $\left(22-24^{\circ} \mathrm{C}, 70-80 \%\right.$ humidity, $12 \mathrm{~h}$ light-darkness periodicity). The animals had rat chow and tap water ad libitum.

All surgery was done under ether anesthesia. The head of the animal was fixed in a stereotaxic apparatus in a $45-55^{\circ} \mathrm{C}$ nose-down position. The occipital muscles were separated in the midline and the atlanto-occipital membrane was cut. The obex was used as the reference point. Glass knives made from cover slips were used for the transections and were $0.08 \mathrm{~mm}$ thick and $1.5 \mathrm{~mm}$ wide; teflon-insulated stainless nichromsteel electrodes with a $100 \mu \mathrm{m}$ diameter and a $200 \mu \mathrm{m}$ long free tip were used for the lesions. A $1.5 \mu \mathrm{A}$ current was applied for $10 \mathrm{sec}$. Five types of interventions were carried out (Fig. 1) as follows. (1) A dorsal medullary transection made by cutting the coronal plane bilaterally $0.5-1.0 \mathrm{~mm}$ before rostral to the obex level, perpendicular to the medulla (Fig. 1A). This transection extended only $0.5-0.8 \mathrm{~mm}$ ventral to the IVth ventricle and transected the solitary tract and the dorsal part of the tegmentum rostral to the A2 cell group, but did not damage the reticular formation and the ascending ventral noradrenergic bundle (Fig. 1B). (2) For transection of the ventral noradrenergic bundle, the cut was similar to that in procedure 1 , but was only made unilaterally and $1 \mathrm{~mm}$ deeper. In addition to the structures cut by the dorsal transection, the ventral noradrenergic bundle and fiber tracts running through the reticular formation were severed in this procedure (Fig. 1C). (3) Total medullary transection was made with a unilateral cut, like the cut in procedure 2 but with the knife lowered to the base of the skull. Only the lateral part of the medulla, i.e. the inferior cerebellar peduncle, the spinal trigeminal tract and its nucleus, remained intact (Fig. 1D). (4) Lesions of the $C 2$ cell group were made with a bilateral lesion extending from before the obex to $1-1.5 \mathrm{~mm}$ caudally, which 

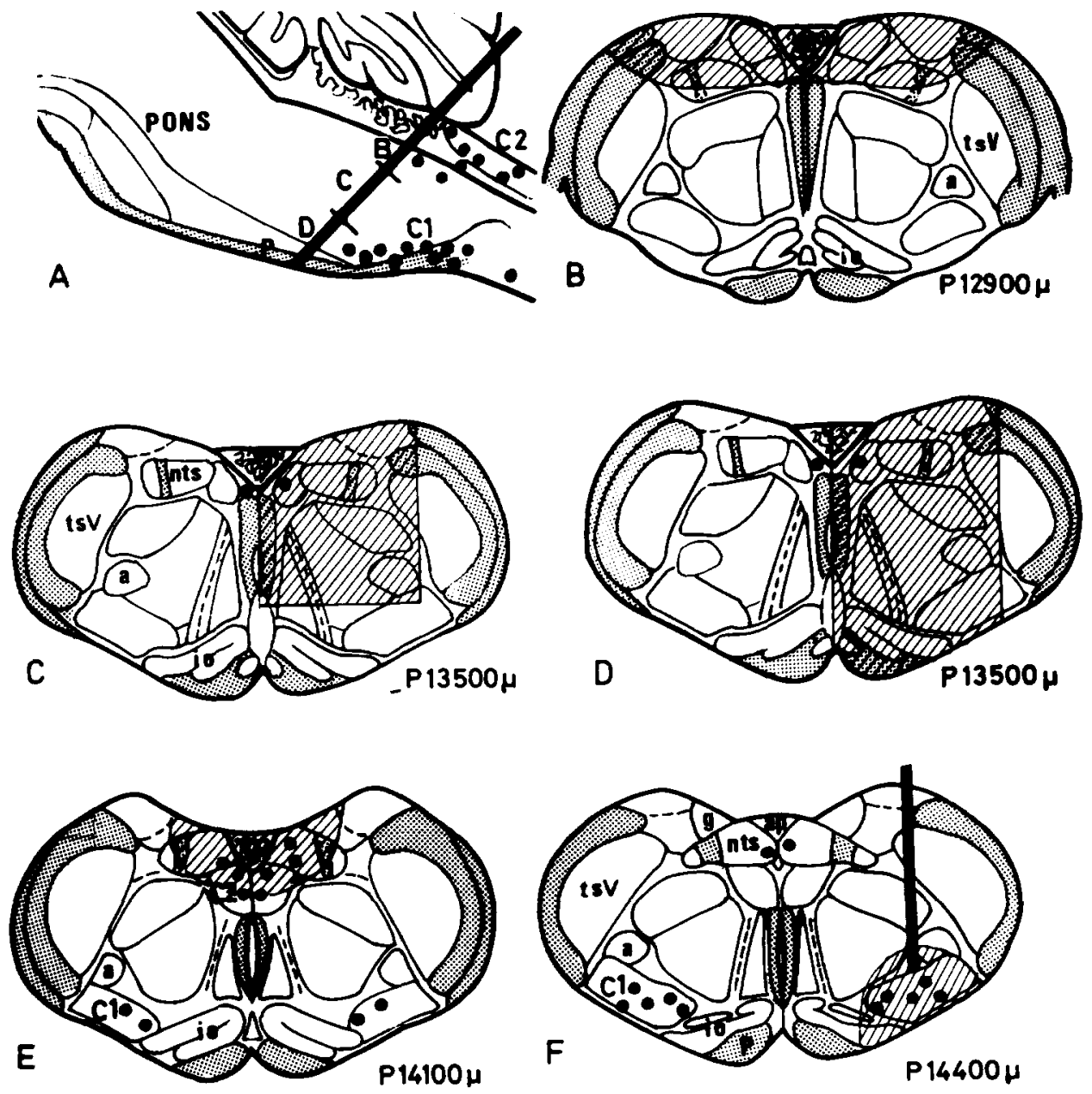

Fig. 1. Schematic drawings to demonstrate the topography of electrolytic lesions and surgical transections in the medulla oblongata. A: sagittal drawing of the lower brain stem with the C1 and C2 adrenaline-containing cell groups. Planes and depth of the medullary transections are demonstrated. B-D: the extent of the interventions in the coronal plane. B: dorsal medullary transection; $\mathrm{C}$ : transection of the ventral noradrenergic bundle and the reticular formation; D: total medullary hemisection. E: bilateral lesion of the $\mathrm{C} 2$ catecholamine cell groups. F: unilateral lesion of the $\mathrm{C} 1$ cell groups. Distances between the level of the transection and the bregma are expressed in $\mu \mathrm{m}$ on the coronal plane schematic drawings. Abbreviations: a, nucleus ambiguus; $g$, nucleus gracilis; io, inferior olive; nts, nucleus of the solitary tract; $\mathrm{ntV}$, nucleus tractus spinalis of nervi trigemini; $\mathrm{nV}$, nucleus motorius nervi trigemini; os, superior olive; $P$, pyramidal tract; VII, facial nerve.

destroyed cell groups above the central canal, including the NTS, the dorsal vagal nucleus (DVN) and the area postrema (Fig. 1E). (5) A lesion of the C1 cell group was made at the obex level $1.8-2.2 \mathrm{~mm}$ from the midline, about $4 \mathrm{~mm}$ deep from the dorsal surface of the brain $(0.5 \mathrm{~mm}$ back from the ventral surface). The average 
diameter of the lesioned area was $0.8-1.2 \mathrm{~mm}$. The lateral reticular nucleus and the area between the inferior olive and the nucleus of the spinal trigeminal tract were destroyed (Fig. 1F).

The animals were killed 7-10 days after operation for biochemical measurements and two days after operation for demonstrating the nerve terminal degeneration by electron microscopy. The biochemical and electron microscopic studies were undertaken after the location of the lesions had been verified by light microscopy. Brains with wrongly placed lesions were discarded.

Immediately following decapitation the brains were frozen on dry ice, cut into 300 $\mu \mathrm{m}$ thick sections in a cryostat at $-10^{\circ} \mathrm{C}$. The punch technique $[13,14]$ was used to remove the hypothalamic nuclei and the median eminence. Adrenaline levels were determined with an enzymatic isotopic method [24]. The protein content of the samples was determined by the method of Lowry et al. [11] and the adrenaline concentrations were calculated as $\mathrm{ng} / \mathrm{mg}$ protein.

Adrenaline concentrations were relatively low in all the hypothalamic nuclei investigated and in the median eminence $(0.87-3.21 \mathrm{ng} / \mathrm{mg}$ protein). Subtotal transections in the medulla caused slight decreases in the hypothalamic adrenaline levels which only reached significance in the paraventricular nucleus following dorsal transection (Table I). Total unilateral transections of the medulla decreased

\section{TABLE I}

ADRENALINE LEVELS IN THE HYPOTHALAMIC NUCLEI FOLLOWING LESIONS AND TRANSECTIONS IN THE MEDULLA OBLONGATA OF THE RAT

( ) Number of animals (lesioned + sham). ${ }^{*} P<0.05$; ${ }^{*} P<0.01$.

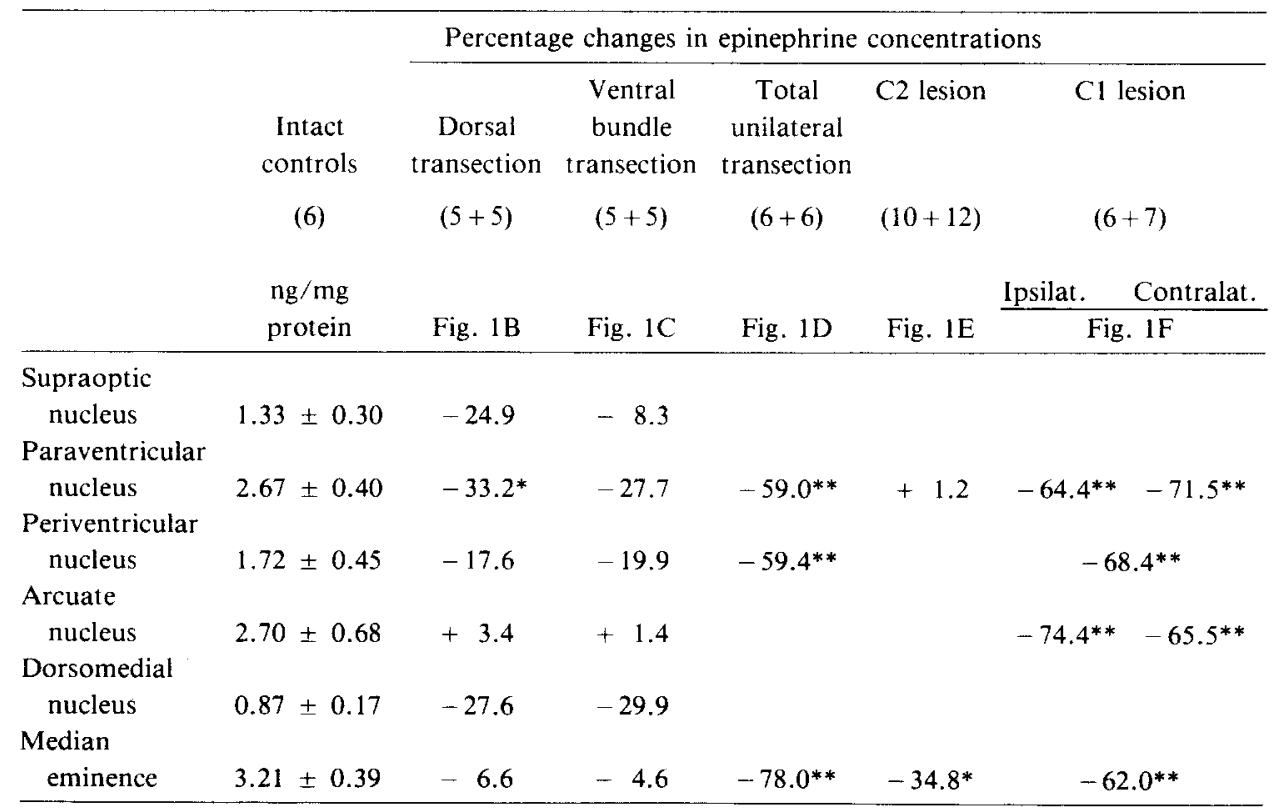


the adrenaline concentration in the median eminence, the periventricular and the paraventricular nuclei by $59-78 \%$. The similar decrease detected after the lesion of the $\mathrm{Cl}$ cell group points to this cell group as the place of origin of hypothalamic adrenaline (Table I). Some of the ascending fibers probably decussate as the decrease in adrenaline levels could be detected bilaterally.

The electrolytic lesion of the $\mathrm{C} 2$ group reduced the adrenaline content of the median eminence by $34.8 \%$ but did not alter the adrenaline content of the paraventricular nucleus (Table I).

No perikarya could be found in the hypothalamus in contrast to the relatively high number of adrenaline nerve terminals detected there. Following surgical isolation of the hypothalamus, the PNMT activity of the arcuate nucleus and the median eminence decreased by $58-66 \%$ [1], suggesting an extrahypothalamic origin for the adrenaline in that area. As - up to now - adrenaline-containing cell bodies have only been found in the medulla [6], this region is likely to be the source of the hypothalamic adrenaline-containing nerve terminals.

The changes in adrenaline concentration which followed electrolytic lesioning and have been described here suggest that the bulk of the adrenergic fibers innervating the hypothalamus originate in the neurons of the $\mathrm{C} 1$ cell group. Both the $\mathrm{C} 1$ and the $\mathrm{C} 2$ cell group appear to contribute to the adrenergic innervation of the median eminence (Table I).

After total unilateral medullary transection and following unilateral $\mathrm{C} 1$ lesion hypothalamic adrenaline decreased by $59-78 \%$. At present we have no explanation for these decreases greater than $50 \%$. Brownstein et al. [1] reported that total deafferentation of the hypothalamus resulted in a decrease of hypothalamic PNMT activity of $58-66 \%$. These findings, together with our present results, attest to the medullary origin of the hypothalamic adrenaline. Part of the adrenaline, however, may derive from still unidentified adrenaline-containing neurons in the CNS, or from the postganglionic fibers of the superior cervical ganglion innervating the vessels. The sensitivity of the adrenaline assay is a factor which must be taken into account when the rather low amounts of adrenaline (0.7-1.0 ng/mg protein) remaining in the hypothalamus after total surgical isolation are considered.

Little is known about the topography of the ascending adrenaline-containing fibers. They have been assumed to join the ventral noradrenergic bundle [6, 23]. Adrenergic fibers which terminate in the hypothalamus probably do not follow this route, especially not in the lower part of the medulla oblongata. Transection of the dorsal part of the medulla oblongata, including the solitary tract, dorsal periventricular tract [10], ventral noradrenergic bundle and part of the reticular formation, did not result in a significant decrease in the hypothalamic adrenaline content except for the decrease in the paraventricular nucleus after dorsal transection (Table I).

The retrograde tracing technique (unpublished observation) revealed the ventral topography of the ascending fibers. Fibers run on the ventrolateral part of the 
medulla oblongata close to the surface up to the pontomedullary border where they turn dorsomedially and can be traced under the genu of the facial nerve. This technique obviously provides evidence only for the de facto existence of fibers with such a topography but gives no information about the nature of the transmitter involved.

Surprisingly, the adrenaline level of the contralateral arcuate and paraventricular nuclei decreased similarly to that of the ipsilateral side after the $\mathrm{Cl}$ cell group had been lesioned (Table I). It is known that the ascending catecholaminergic fibers innervating the hypothalamus cross the midline or give off a collateral fiber to the contralateral side on their way up $[10,23]$. These findings were confirmed when nerve terminals in the paraventricular nucleus were found to have degenerated following surgical sagittal transection of the medulla.

In conclusion, biochemical methods are certainly not suitable to resolve the problem of either the detailed topography of the ascending adrenergic pathways or the pattern of hypothalamic adrenergic innervation. Histofluorescence or immunofluorescence techniques are more appropriate experimental approaches to deal with these problems.

\section{REFERENCES}

1 Brownstein, M.J., Palkovits, M., Tappaz, M.L., Saavedra, J.M. and Kizer, J.S., Effect of surgical isolation of the hypothalamus on its neurotransmitter content, Brain Res., 117 (1976) 287-295.

2 Dahlström, A. and Fuxe, K., Evidence for the existence of monoamine-containing neurons in the central nervous system. I. Demonstration of monoamines in the cell bodies of brain stem neurons, Acta physiol. scand., 62, Suppl. 232 (1964) 1-55.

3 De Olmos, J.S. and Carrer, H., A horseradish peroxidase study of the afferent connection of the medial basal hypothalamus in the rat, Anat. Rec., 190 (1978) 380.

4 Elde, R. and Hökfelt, T., Distribution of hypothalamic hormones and other peptides in the brain. In W.F. Ganong and L. Martini (Eds.), Frontiers in Neuroendocrinology, Vol. 5, Raven Press, New York, 1978, pp. 1-33.

5 Feminger, A., Mezey, E. and Palkovits, M., Reciprocal innervation between the hypothalamus and medullary catecholamine-containing cell groups, Verh. anat. Ges. (Jena), in press.

6 Hökfelt, T., Fuxe, K., Goldstein, M. and Johansson, O., Immunohistochemical evidence for the existence of adrenaline neurons in the rat brain, Brain Res., 66 (1974) 235-252.

7 Johansson, O., Hökfelt, T., Elde, R.P., Schultzberg, M. and Terenius, L., Immunohistochemical distribution of enkephalin neurons, Advanc. Biochem. Psychopharmacol., 18 (1978) 51-70.

8 Koslow, S.H. and Schlumpf, M., Quantitation of adrenaline in rat brain nuclei and areas by mass fragmentography, Nature (Lond.), 251 (1974) 530-531.

9 Lew, J.Y., Matsumoto, Y., Pearson, J., Goldstein, M., Hökfelt, T. and Fuxe, K., Localization and characterization of phenylethanolamine $\mathrm{N}$-methyltransferase in the brain of various mammalian species, Brain Res., 119 (1977) 199-210.

10 Lindvall, $\mathrm{O}$. and Björklund, A., The organization of the ascending catecholamine neuron systems in the rat brain as revealed by the glyoxylic acid fluorescence method, Acta physiol. scand., Suppl. 412 (1974) $1-48$.

11 Lowry, O.H., Rosebrough, N.J., Farr, A.L. and Randall, R.J., Protein measurement with Folin phenol reagent, J. biol. Chem., 193 (1951) 265-275. 
12 Mefford, I., Oke, A., Adams, R.N. and Jonsson, G., Epinephrine distribution in human brain, Neurosci. Lett., 9 (1978) 227-231.

13 Palkovits, M., Isolated removal of hypothalamic or other brain nuclei of the rat, Brain Res., 59 (1973) 449-450.

14 Palkovits, M., Isolated removal of hypothalamic nuclei for neuroendocrinological studies. In W.E. Stumpf and L.D. Grant (Eds.), Anatomical Neuroendocrinology, Karger, Basel, 1975, pp. 72-80.

15 Palkovits, M., Léránth, Cs., Záborszky, L. and Brownstein, M.J., Electron microscopic evidence of direct neuronal connections from the lower brain stem to the median eminence, Brain Res., 136 (1977) 339-344.

16 Palkovits, M., Mezey, É. and Záborszky, L., Neuroanatomical evidences for direct neuronal connections between the brain stem baroreceptor centers and the forebrain areas involved in neural regulation of the blood pressure. In P. Meyer and H. Schmitt (Eds.), Nervous System and Hypertension, Wiley-Flammarion, Paris, 1979, pp. 18-30.

17 Palkovits, M. and Záborszky, L., Neuroanatomy of central cardiovascular control. Nucleus tractus solitarii: afferent and efferent neuronal connections in relation to the baroreceptor reflex arc, In W. de Jong, A.P. Provoost and A.P. Shapiro (Eds.), Hypertension and Brain Mechanisms, Progress in Brain Research, Vol. 47, Elsevier, Amsterdam, 1977, pp. 9-34.

18 Ricardo, J.A. and Koh, E.T., Anatomical evidence of direct projections from the nucleus of the solitary tract to the hypothalamus, amygdala and other forebrain structures in the rat, Brain Res., 153 (1978) $1-26$.

19 Saavedra, J.M., Palkovits, M., Brownstein, M.J. and Axelrod, J., Localization of phenylethanolamine $\mathrm{N}$-methyltransferase in the rat brain nuclei, Nature (Lond.), 248 (1974) $695-696$.

20 Silver, M.A., Jacobowitz, D.M., Crowley, W. and O'Donohue, T., Retrograde transport of dopamine- $\beta$-hydroxylase antibody $(\mathrm{AD} \beta \mathrm{H})$ by $\mathrm{CNS}$ noradrenergic neurons: hypothalamic noradrenergic innervations, Anat. Rec., 190 (1978) 541.

21 Uhl, G.R., Goodman, R.R., Kuhar, M.J., Childers, S.R. and Snyder, S.H., Immunohistochemical mapping of enkephalin containing cell bodies, fibers and nerve terminals in the brain stem of the rat, Brain Res., 166 (1979) 75-94.

22 Uhl, G.R., Goodman, R.R. and Snyder, S.H., Neurotensin-containing cell bodies, fibers and nerve terminals in the brain stem of the rat: immunohistochemical mapping, Brain Res., 167 (1979) $77-91$.

23 Ungerstedt, U., Stereotaxic mapping of the monoamine pathways in the rat brain, Acta physiol. scand., 82, Suppl. 367 (1971) 1-48.

24 Van der Gugten, J., Palkovits, M., Wijnen, H.J.L.M. and Versteeg, D.H.G., Regional distribution of adrenaline in rat brain, Brain Res., 107 (1976) 171-175.

25 Záborszky, L. and Palkovits, M., Afferent brain stem connections of the medio-basal hypothalamus. In Proc. Int. Symp. Neuroendocr. Reg. Mech., Scientific Assemblies, Vol. VI, Serbian Acad. Sci. Arts, Belgrade, 1979, pp. 153-164. 